Vol. 34(2):111-123

http://dx.doi.org/10.4217/OPR.2012.34.2.111

\title{
Article
}

\author{
황해 동부 해역에서 하계에 조석전선과 용승에 의한 \\ 식물플랑크톤군집 분포 \\ 이영주 ${ }^{1} \cdot$ 최중기 $^{1 *} \cdot$ 손재경 $^{2}$ \\ 1인하대학교 자연과학대학 해양학과 \\ (402-751) 인천시 남구 인하로 100 \\ 2국립수산과학원 서해수산연구소 자원환경과 \\ (400-420) 인천시 중구 을왕동 선녀바위로 14
}

\section{Phytoplankton Distribution in the Eastern Part of the Yellow Sea by the Formation of Tidal Front and Upwelling during Summer}

\author{
Youngju Lee ${ }^{1}$, Joong Ki Choi ${ }^{1 *}$, and Jae-Kyoung Shon ${ }^{2}$ \\ ${ }^{1}$ Department of Oceanography, College of Natural Science \\ Inha University, Incheon 402-751, Korea \\ ${ }^{2}$ West Sea Fisheries Research Institute, NFRDI \\ Incheon 400-420, Korea
}

\begin{abstract}
To understand the phytoplankton community in the eastern part of the Yellow Sea (EYS), in the summer, field survey was conducted at 25 stations in June 2009, and water samples were analyzed using a epifluorescence microscopy, flow cytometry and HPLC method. The EYS could be divided into four areas by a cluster analysis, using phytoplankton group abundances: coastal mixing area, Anma-do area, transition water, and the central Yellow Sea. In the coastal mixing area, water column was well mixed vertically, and phytoplankton was dominated by diatoms, chrysophytes, dinoflagellates and nanoflagellates, showing high abundance $\left(>10^{5}\right.$ cells $\left.~^{-1}\right)$. In Anma-do coastal waters characterized by high dominance of dinoflagellates, high phytoplankton abundance and biomass separated from other coastal mixing area. The southeastern upwelling area was expanded from Jin-do to Heuksan-do, by a tidal mixing and coastal upwelling in the southern area of Manjae-do, and phytoplankton was dominated by benthic diatoms, nanoflagellates and Synechococcus group in this area. Phytoplankton abundance and biomass dominated by pico- and nanophytoplankton were low values in the transition waters and the central Yellow Sea. In the surface of the central Yellow Sea, high dominance of photosynthetic pigments, 19'-hexanoyloxyfucoxanthin and zeaxanthin implies that haptophytes and cyanobacteria could be the dominant group during the summer. These results indicate that the phytoplankton communities in the EYS were significantly affected by the formation of tidal front, thermal stratification, and coastal upwelling showing the differences of physical and chemical characteristics during the summer.
\end{abstract}

Key words : phytoplankton, Yellow Sea, photosynthetic pigments, picophytoplankton, tidal front, coastal upwelling

*Corresponding author. E-mail : jkchoi@inha.ac.kr 


\section{1. 서 론}

식물플랑크톤은 해양생태계에서 일차생산자로서 중요 한 역할을 한다. 식물플랑크톤의 생물량과 생산력은 환경 적인 요인이나 동물플랑크톤의 섭식에 의하여 영향 받는 다. 황해는 한국과 중국으로 둘러싸인 반폐쇄성 연해 (marginal sea)로써 남으로 동중국해와 연결되어 있다. 평 균수심은 $44 \mathrm{~m}$, 최대수심 $100 \mathrm{~m}$ 로 세계적으로 가장 크고 얕은 대륙붕 중 하나이며 생물 생산성이 높은 것으로 알 려져 있다(Tang 2003). 황해는 조석에 의한 강한 조류, 황 해난류수, 황해저층냉수, 양자강수, 연안수 등에 의하여 복잡하게 영향 받으며 황해에서 식물플랑크톤의 분포는 이러한 복잡한 수괴에 의해 영향 받을 것으로 보인다.

황해는 춘계와 추계에 식물플랑크톤 생체량이 증가하는 전형적인 온대수역의 특성을 보이며 생산성이 높은 해역 으로 알려져 있다(Heileman and Jiang 2009). 황해 중앙해 역에서 하계와 추계에는 소형 크기 $(>20 \mu \mathrm{m})$ 의 식물플랑 크톤이 약 $35 \%$ 를 차지하나 동계와 춘계에는 $50 \%$ 이상으 로 높은 우점율을 차지한다(Choi 2002). 한국의 서해 연안 인 황해 중동부수역의 연안쪽은 하계에도 조석혼합에 의 해 수괴가 잘 혼합되고, 바깥 수역은 조석작용의 약화로 수직적으로 성층이 형성된다. 이 혼합수괴와 성층수괴 사 이에 조석전선이 발달하며 조석전선 내측의 연안 혼합수 역과 전선수역, 그리고 바깥쪽의 성층수역에서 식물플랑 크톤 현존량과 크기구조, 종조성, 생산력이 다른 특성을 보이는 것으로 보고되어 있다(최 1991; 조 등 1999; 윤 등 2007). 연안 혼합수역은 연안성 규조류가 우점하며 엽록 소-a 농도가 높으나 낮은 투명도로 일차생산은 낮게 나타 나고 성층수역은 낮은 엽록소-a 농도에도 깊은 유광층 형 성으로 높은 일차생산력을 보이며 표층에서는 $20 \mu \mathrm{m}$ 이 하의 미소형 식물플랑크톤이 우점하여 나타난다. 혼합수 역과 성층수역의 사이에 나타나는 전선수역은 높은 생물 량과 생산력을 보이며 연안종과 외양종이 혼재하여 나타 나 다양성이 높은 것으로 알려져 있다. 이러한 차이는 각 해역의 성층과 수직혼합 양상에 의한 영양염 공급, 투명 도, 수괴 안정도 등이 요인인 것으로 연구되어 있다. 그러 나 기존의 연구들은 대부분 $20 \mu \mathrm{m}$ 이상 크기의 소형식물 플랑크톤에 관한 연구이며 $20 \mu \mathrm{m}$ 이하의 미소형 식물플 랑크톤은 크기별 엽록소-a 농도 및 일차생산력을 통한 연 구만 주로 이루어져 작은 크기의 식물플랑크톤 군집에 관 한 연구는 부족한 실정이다.

본 연구에서는 하계에 황해 동부수역의 수괴분포에 따 른 크기 및 분류군별 식물플랑크톤 군집분포를 분석하여 조석전선과 같은 물리적 요소에 의한 환경 변화가 식물 플랑크톤 각 그룹의 분포에 미치는 영향을 이해하고자 하였다.

\section{2. 재료 및 방법}

\section{현장조사}

황해 동부 수역의 하계 현장조사는 국립수산과학원 서 해수산연구소의 서해해양조사에 참여하여 2009년 6월 26 일 7월 3 일의 기간 동안 307 선 312 선의 25 개 정점에서 조사선(탐구 8호)을 이용하여 이루어졌으며(Fig. 1) 각 정 점의 표층, $10 \mathrm{~m}, 20 \mathrm{~m}, 30 \mathrm{~m}, 50 \mathrm{~m}, 75 \mathrm{~m}$, 저층의 수심 에서 니스킨 채수기를 이용하여 해수를 채집하였다.

\section{물리, 화학적 환경요인}

황해 동부 수역의 수온, 염분 , 투명도 및 용존 무기 영 양염 중 질산염, 아질산염을 포함하는 질소계 영양염 (Dissolved nitrite and nitrate; DNN)과 인산염(P), 규산염 (Si)은 국립수산과학원 한국해양자료센터 홈페이지(http:// kodc.nfrdi.re.kr)에서 같은 조사 기간 동안 얻어진 자료를 활용하였다.

\section{식물플랑크톤 정량연구 \\ 미소형 및 소형 식물플랑크톤}

표층에서 채집된 해수 $200 \mathrm{ml}$ 를 HDPE(High Density Polyethylene) 병에 넣고 글루타알데히드(glutaraldehyde, 최종농도 $1 \%$ )로 고정하여 분석 전까지 $-20^{\circ} \mathrm{C}$ 에 냉동보관 하였다. 돌말류와 편모조류 관찰을 위하여 $50 \sim 100 \mathrm{ml}$ 를 Gelman GN-6 Metricel filters $(0.45 \mu \mathrm{m}$ pore size, $25 \mathrm{~mm}$ 직경)에 낮은 압력(1/3 atm 이하)으로 여과한 후 HPMA (2-hydroxypropyl methacrylate)로 슬라이드를 제작하였다 (Crumpton 1987; Kang and Fryxell 1991; Kang et al. 2001). 정량분석을 위하여 임의의 필드에서 30 필드 혹은 300 개체까지 계수하였다. $20 \mu \mathrm{m}$ 이상 크기의 소형식물플

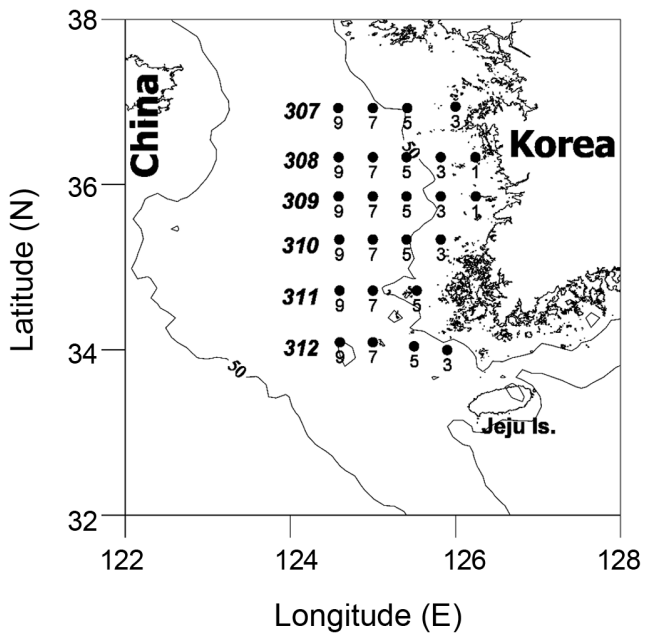

Fig. 1. Sampling stations and bathymetry of study area in the eastern part of the Yellow Sea 
랑크톤은 광학현미경(Olympus, BX50) 하에서 계수하였 고 2 20 $\mu \mathrm{m}$ 크기의 미소식물플랑크톤은 blue excitation filter가 장착된 형광현미경(Nikon 104) 하에서 600 1500 배의 배율로 계수하였다.

\section{초미소식물플랑크톤}

표층에서 채집된 해수 $4 \mathrm{ml}$ 를 cryogenic 튜브에 넣고 $10 \%$ 파라포름알데히드(paraformaldehyde) $0.4 \mathrm{ml}$ 을 첨가 하여 약 15 분 동안 실온에서 고정하였으며 액체질소에 보 관하였다. 분석 전까지 $-80^{\circ} \mathrm{C}$ 에 보관되었으며 분석 직전 시료를 녹인 후 산란과 형광을 표준화하기 위한 내부표준 물질 yellow-green fluorescent microsphere $(0.5 \mu \mathrm{m}$ 직경 의 beads; Polysciences Inc., USA)를 혼합하여 사용하였 다. 초미소식물플랑크톤 세 그룹인 Prochlorococcus, Synechococcus, pico-eukaryotes의 개체수는 $488 \mathrm{~nm}$ 의 아 르곤 이온 레이저가 장착된 유세포분석기(flow cytometer, FACSCalibur $^{\mathrm{TM}}$, Becton Dickinson and Company, USA) 를 이용하여 계수하였다(Marie et al. 1997). 초미소식물플 랑크톤은 $90^{\circ}$-angle light scatter(SSC)와 엽록소에 의한 적 색형광(red fluorescence), phycoerythrin에 의한 오렌지색 형광(orange fluorescence) 특성 등을 이용하여 분리, 계수 하였다. Pico-eukaryotes 그룹은 yellow-green fluorescent microsphere $(0.5 \mu \mathrm{m}, \quad 0.95 \mu \mathrm{m}, \quad 2 \mu \mathrm{m}$ 직경의 beads; Polysciences Inc., USA)를 이용하여 forward light scatter (FSC) 값으로 $2 \mu \mathrm{m}$ 이상과 이하의 크기를 구분하였다. $2 \mu \mathrm{m}$ 이상 크기는 현미경 관찰 결과와의 중복을 피하기 위하여 제외하였고, $2 \mu \mathrm{m}$ 이하 크기의 pico-eukaryotes 개 체만 현존량 계산에 사용되었다. 유세포분석기에서 산출 된 자료는 FlowJo 프로그램(Tree Star, Inc., www.flowjo. com)을 이용하여 분석하였다.

\section{크기별 엽록소-a 농도}

표층해수의 엽록소-a 농도는 $20 \mu \mathrm{m}$ 이상과 이하의 크 기 구배에서 측정되었다. 표층에서 채집된 해수 및 $20 \mu \mathrm{m}$ 망에 거른 해수 0.5 1 를 유리섬유여과지(GF/F, Whatman) 에 각각 여과하여 냉동보관하였다(Sieburth 1978; Takahashi and Bienfang 1983). 추출을 위해 $90 \%$ 아세톤에 여과지를 넣어 냉암소에서 보관하였고, 24시간 후 유리섬유여과지 $(\mathrm{GF} / \mathrm{F})$ 로 여과하여 입자 및 추출 여과지를 걸러낸 후 표준 엽록소-a(Sigma)로 보정된 형광광도계(fluorometer; 10$\mathrm{AU}$, Turner Designs, USA)를 이용하여 흡광도를 측정하 였으며, UNESCO (1976) 계산식을 통하여 계산하였다 (Parson et al. 1984). $20 \mu \mathrm{m}$ 이하 크기구배의 엽록소-a 농 도는 직접 측정되었고, $20 \mu \mathrm{m}$ 이상 크기구배의 엽록소-a 농도는 전체 엽록소-a 농도와 $20 \mu \mathrm{m}$ 이하 크기구배의 엽 록소-a 농도차로 계산하였다.

\section{식물플랑크톤 색소분석}

각 수심별로 채집된 해수 11 를 직경 $47 \mathrm{~mm}$ 의 유리섬 유여과지(GF/F, Whatman)에 여과하여 분석 전까지 $-80^{\circ} \mathrm{C}$ 에 보관하였다. 여과지는 $95 \%$ 메탄올 $3 \mathrm{ml}$ 에 넣고 5 분 동 안 초음파처리(ultrasonication) 되었으며 분석 전까지 냉 암소에서 24시간 추출되었다. 분석을 위해 $25 \mathrm{~mm}$ 직경의 테프론 syringe filter(MFS, $0.2 \mu \mathrm{m}$ pore size)로 추출액을 거른 후, 피크의 왜곡을 피하기 위하여 분석 직전 추출액 $1 \mathrm{ml}$ 에 $0.2 \mathrm{ml}$ 의 3 차 증류수를 첨가하였다. 식물플랑크톤 광합성 색소분석을 위하여 고성능 액체 크로마토그래피 (HPLC, Shimadzu VP series, Japan)가 이용되었으며 21개 의 표준 색소를 이용하여 보정되었다(DHI Water \& Environment, Denmark). 색소분석은 Zapata et al. (2000) 의 방법을 따랐다. 피크의 분리를 위해 C8 column(Luna $\mathrm{C} 8$ (2) 100A, Phenomenex, USA)이 사용되었다. 색소는 photodiode array detector(SPD-M10AVP)를 사용하여 $440 \mathrm{~nm}$ 에서 검출되었고 각 피크의 스펙트럼 $(350 \sim 750 \mathrm{~nm})$ 또한 분석되었다. 각 피크의 머무름 시간은 표준색소의 머 무름 시간과 비교하여 구분하였으며 response factor는 표 준색소의 주입량(ng)과 peak 면적의 비율로 계산하였다. 표준색소의 농도는 분광광도계(spectrophotometry)로 측정 된 최대흡광도 파장과 알려져 있는 각 표준색소의 흡광계 수를 이용하여 보정되었으며 샘플에서 분석된 색소의 농 도는 Mantoura and Repeta (1997)의 식에 의하여 계산되 었다.

\section{3. 결과 및 고찰}

\section{황해 동부해역의 환경특성 수온, 염분, 투명도}

2009년 6월에 황해 동부수역의 표층에서 수온은 16.3 $23.1^{\circ} \mathrm{C}$ 의 분포를, 염분은 $31.7 \sim 33.1 \mathrm{psu}$ 의 분포를 보였다 (Fig. 2). 표층 수온 분포는 북동쪽 정점인 태안반도 인근 해역에서 낮은 수온을 보였으며, 특히 흑산도부터 가거도 에 이르는 311 선 정점 5 와 312 선 정점 5 인근해역의 표층 에서 주변수역보다 수온이 약 $5^{\circ} \mathrm{C}$ 낮은 냉수대가 관찰되 었다. 투명도 수심은 3.0 14.0 m의 분포로 307선의 정점 3 에서 가장 낮았고 310 선의 정점 5 에서 가장 깊은 투명도 수심을 보였다. 흑산도 인근해역에서 투명도 수심이 다소 얕아지는 양상을 보였으나 전반적으로 연안에서 외해쪽으 로 가면서 투명도 수심이 급격하게 깊어지는 경향을 나타 냈다(Fig. 2). 수온과 염분의 수직분포는 연안쪽과 바깥쪽 정점에서 다소 달랐는데 바깥해역에 위치한 정점에서는 하계에 표층수온 증가로 인하여 성층이 강화되어 수온과 염분의 수직분포차가 크게 나타난 반면 연안쪽 정점에서 는 수직적으로 다소 혼합되는 양상을 보였다(Fig. 3). 


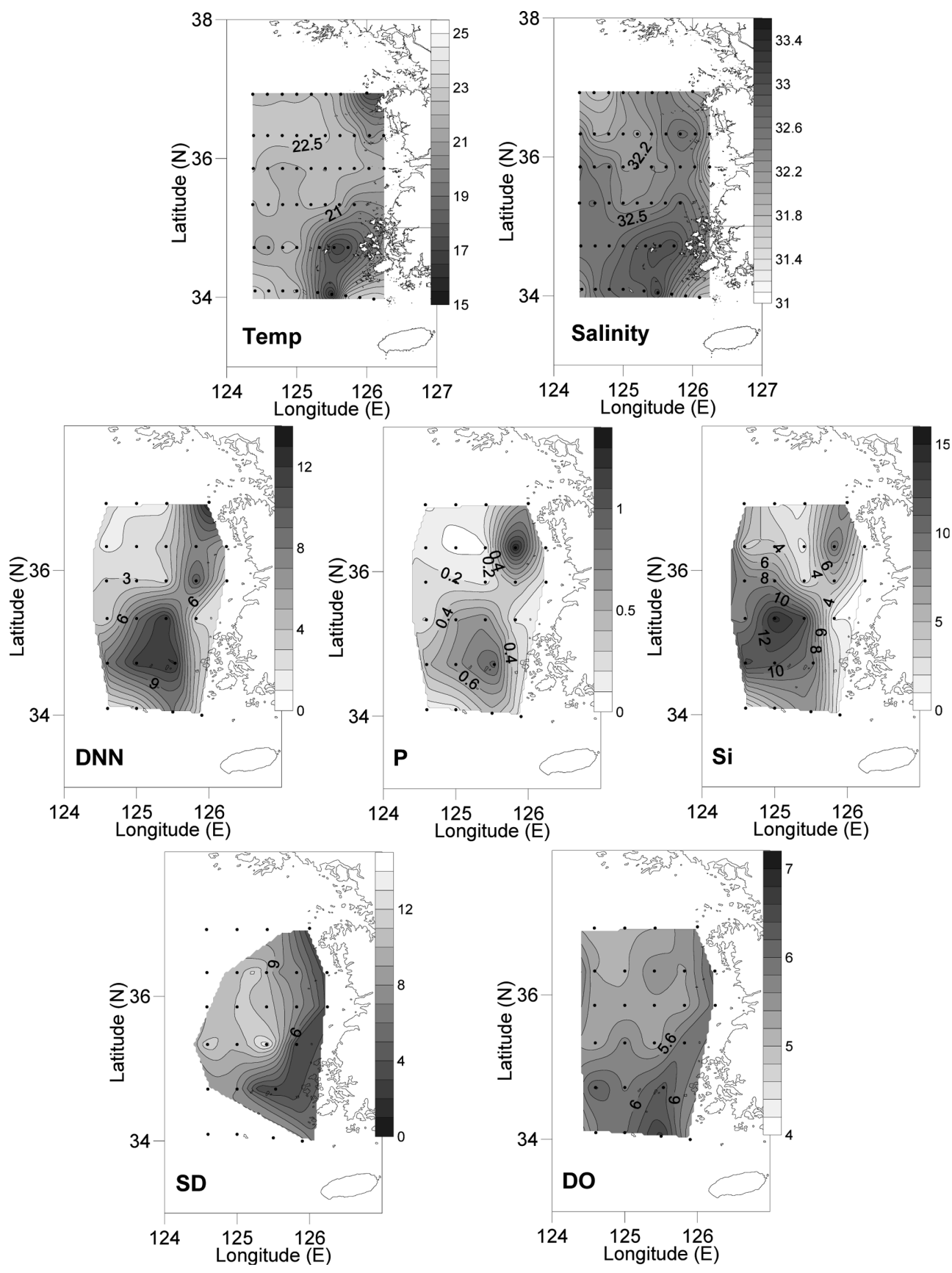

Fig. 2. Spatial distributions of environmental parameters in the surface layer of the eastern part of the Yellow Sea in summer 2009. Abbreviations: Temp, temperature $\left({ }^{\circ} \mathrm{C}\right)$; DNN, dissolved nitrite and nitrate $(\mu \mathrm{M})$; $P$, phosphate $(\mu \mathrm{M}) ; \mathrm{Si}$, silicate $(\mu \mathrm{M})$; SD, secchi disc depth $(\mathrm{m})$; DO, dissolved oxygen $\left(\mathrm{mg} \mathrm{l}^{-1}\right)$

하계에 황해 동부해역은 조석전선에 의하여 물리 화학 적 수괴 구조가 크게 변하는 것으로 보인다. 염분의 수평 분포를 살펴보면 각 선의 가장 연안쪽에 위치한 정점에서 낮은 염분을 보이며 바깥해역 쪽으로 수평경사가 크게 나 타나 하계에 육상으로부터 유입되는 담수의 영향이 나타 나는 것으로 생각된다. 연안쪽 정점에서 염분은 수직적으 로 균일한 분포를 보였는데(Fig. 3) 이는 육상으로부터 유
입되는 저염의 해수가 조석에 의하여 수직 혼합되어 나타 난 것으로 생각된다. 또한 염분의 수직분포는 조사해역의 북쪽과 남쪽이 다소 달랐는데 북쪽에 위치하는 307선과 308선의 연안쪽 정점들에서는 수직적으로 균일하고 수평 적으로 염분의 구배를 보인 반면 309선과 310선은 연안쪽 정점에서도 수직 경사가 존재하였다. 이러한 차이는 북쪽 에 비하여 남쪽 정점이 수심이 깊고 조석차가 비교적 크 
(a) Temperature

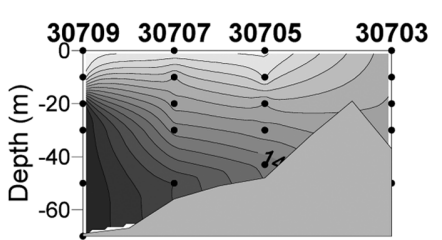

$30809308073080530803 \quad 30801$

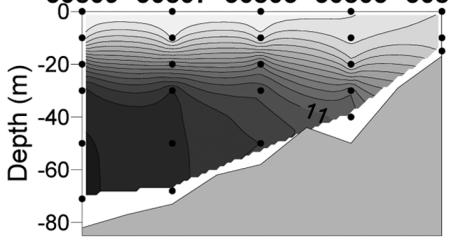

$3090930907 \quad 30905 \quad 30903 \quad 309$

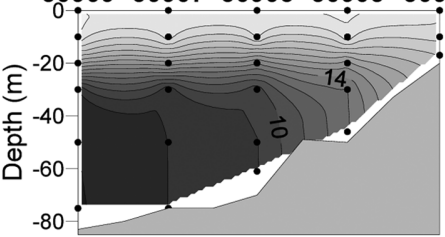

31009310073100531003
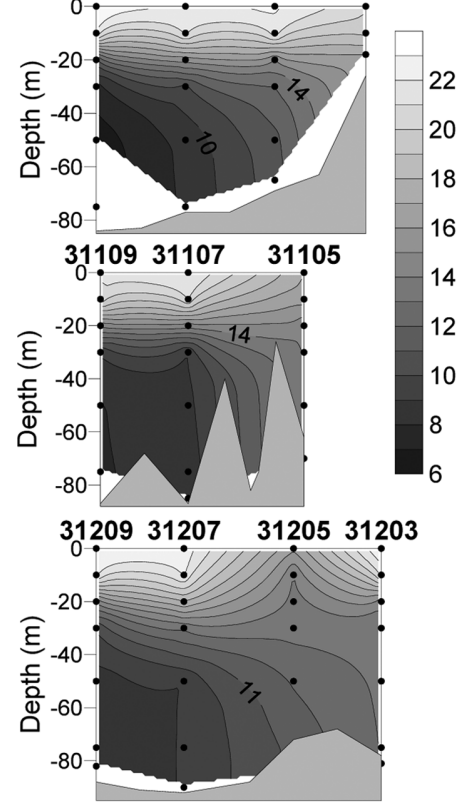

(b) Salinity

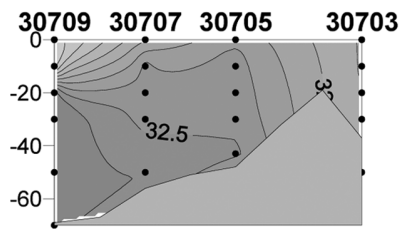

(c) Dissolved nitrite and nitrate

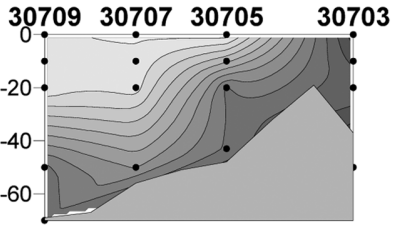

$308093080730805 \quad 30803 \quad 3080130809308073080530803 \quad 30801$

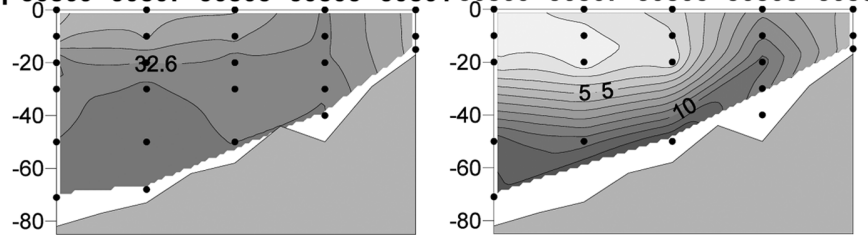

$30909309073090530903 \quad 3090130909309073090530903 \quad 30901$
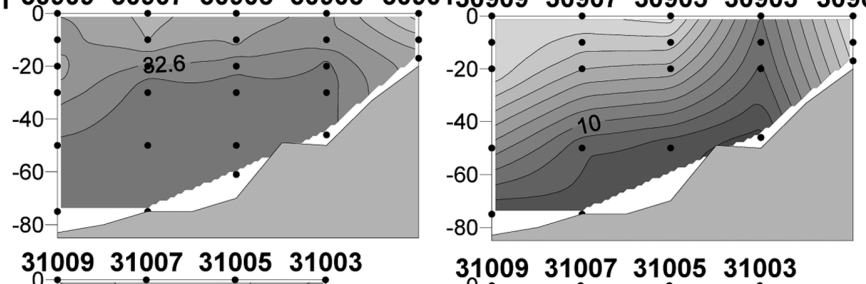

31009310073100531003

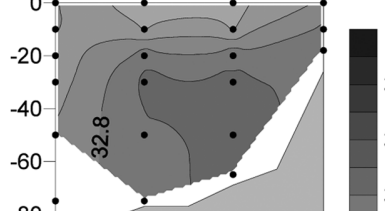

$-80^{\circ}$

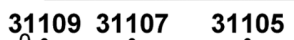

33.8

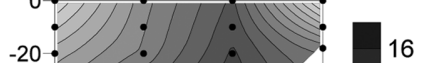
$-40$

33.4

$-60-$
$-80-$
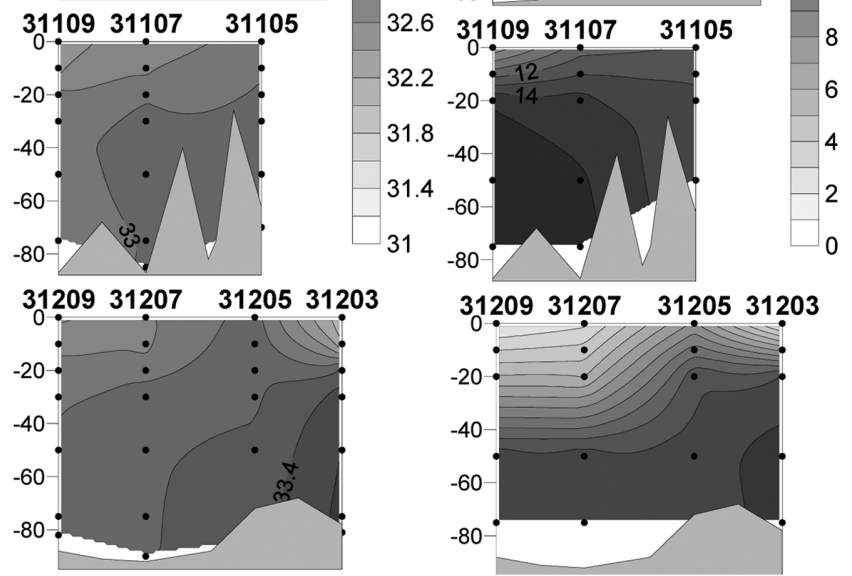

Fig. 3. Vertical distributions of (a) water temperature $\left({ }^{\circ} \mathrm{C}\right)$, (b) salinity (psu) and (c) dissolved nitrite and nitrate $(\mu \mathrm{M})$ in the eastern part of the Yellow Sea in summer 2009

지 않아 수직혼합에 차이를 보인데 기인하는 것으로 판단 된다. 태안 인근해역과 흑산도 인근해역에서는 활발한 수 괴의 수직혼합으로 인하여 낮은 표층수온을 나타냈다. 수 온, 염분, 밀도, 성층계수 등 물리적 파라미터를 이용한 기 존 연구들은 태안 인근해역과(Seung et al. 1990) 진도 및 흑산도 인근해역에서(정 등 2009) 하계에 조석전선이 발 달하여 나타나는 것으로 보고하고 있다. 본 연구 결과 수 온의 수직구조는 대부분의 정선에서 가장 연안쪽 정점이 외해쪽에 비하여 수직적으로 비교적 잘 혼합되는 연안 혼
합수역으로 구분되었으나 남쪽 정점인 311과 312선에서 는 다소 다른 양상을 나타냈다. 다소 바깥쪽 해역인 흑산 도 인근정점에서 표층의 저수온 현상이 나타났으며 염분 은 $33 \mathrm{psu}$ 이상을 보였다. 또한 만재도 남쪽해역인 312선 의 정점 5 에서 수온, 염분의 수직분포는 표층쪽으로 쐐기 (wedge) 모양의 구조를 나타냈다. 정 등 (2009)은 진도와 흑산도 인근 해역에서 바깥 수역까지 저수온역이 확장되 는 현상을 조석전선과 함께 진도 남서쪽으로 향하는 강한 조석 잔차류에 의한 것으로 분석한 바 있다. 그러나 황 
(2010)은 하계에 홍도와 흑산도 인근해역에서 연안용승이 발생하며 같은 시기 난류성 어종의 자치어가 출현함을 보 고한 바 있다. 이는 흑산도 인근해역에서 표층 해수의 저 수온 현상이 조석혼합 뿐 아니라 대마난류와 같은 외해수 의 유입으로 인한 연안용승에 의하여 기인될 수 있음을 암시한다. 제주도 서측해역, 일본의 북서쪽 연안해역, 중 국의 남동부인 저장성, 복건성 연안에서도 유사한 현상이 보고되어 있는데 대마난류가 하계에 연안 용승을 일으키 며 이는 연안역에서 수심이 급격히 얕아지는데 가장 큰 원인이 있는 것으로 밝혀져 있다(강 등 1996; Jiang et al. 2007; Nakada et al. 2010). 흑산도 인근해역은 황해 중앙 해역에서 남북으로 이어지는 수심 $50 \mathrm{~m}$ 이상의 골 (trough) 바로 동측에 위치해 있어 수심변화가 급격하게 나타난다. 따라서 황해의 골을 따라 유입되는 해류 혹은 조석에 의한 해수의 움직임이 흑산도 인근해역에서 급격 히 낮아진 수심으로 인해 연안 용승을 발생시키며 이로 인하여 표층에서 저수온 현상, 높은 용존산소, 얕은 투명 도 등이 나타나는 것으로 판단된다.

\section{용존무기영양염}

2009년 6월에 황해 동부수역의 표층에서는 $\mathrm{DNN}$ 이 $1.4 \sim 13.6 \mu \mathrm{M}$ 의 범위로 평균 $5.4 \mu \mathrm{M}$ 의 농도를, 인산염이 $0.1 \sim 1.3 \mu \mathrm{M}$ 의 범위로 평균 $0.4 \mu \mathrm{M}$ 의 농도를, 규산염이 $0.7 \sim 14.5 \mu \mathrm{M}$ 의 범위로 평균 $6.0 \mu \mathrm{M}$ 의 농도를 보였다 (Fig. 2). 용존무기영양염류의 수평적 분포는 $\mathrm{DNN}$, 인산 염, 규산염이 유사한 분포경향을 보였으며 대체로 연안쪽 정점에서 높은 표층 영양염 농도를 나타냈다. 영양염 농도 분포 또한 수온, 염분 분포와 마찬가지로 조사수역의 북쪽 과 남쪽이 달랐는데 북쪽의 307선부터 309선까지는 연안 과 조석전선 수역의 표층에서 높은 영양염 농도 분포를 보이다 외해쪽으로 가면서 급격히 농도가 감소하는 경향 을 나타냈다. 반면에 조사수역의 남쪽인 310선부터 312선 까지의 해역에서는 흑산도 인근해역 뿐 아니라 외해쪽에 서도 비교적 높은 표층 영양염 농도를 보였다.

$\mathrm{DNN}$ 농도의 수직분포를 살펴보면 조사해역 중 북쪽에 위치한 307선부터 310선에서는 정점 3의 표층에서 높은 $\mathrm{DNN}$ 의 농도가 나타났고 311,312 선에서는 정점 5 의 표 층에서 $\mathrm{DNN}$ 의 농도가 높게 나타났다(Fig. 3). 흑산도 인 근해역의 $\mathrm{DNN}$ 농도는 수온, 염분 분포와 마찬가지로 연 안 용승에 의하여 표층쪽으로 쐐기모양의 분포를 보였으 며 이로 인하여 저층으로부터 유입된 영양염이 표층에서 확산되어 나타난 것으로 판단된다.

\section{식물플랑크톤 군집의 분포특성}

미소형 및 소형 식물플랑크톤 현존량 및 우점종

2009년 6월 황해 동부해역의 표층에서 $2 \mu \mathrm{m}$ 이상 크기
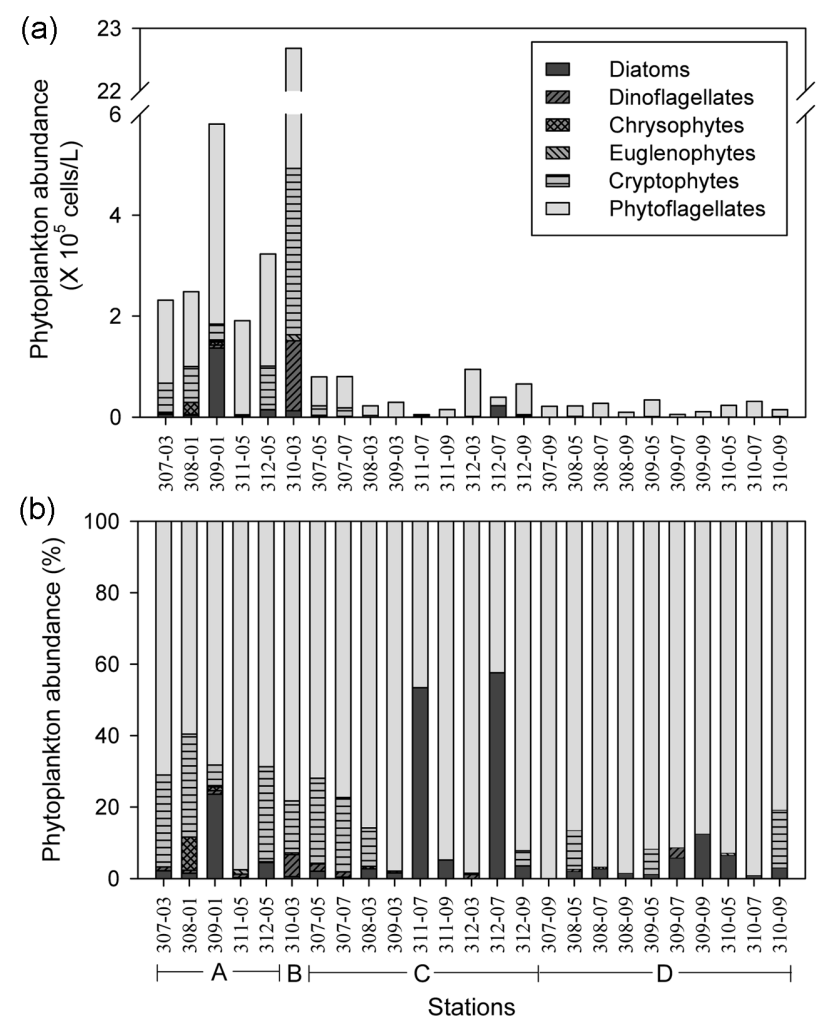

Fig. 4. Regional variations of (a) phytoplankton group abundance (cells $\mathrm{I}^{-1}$ ) and (b) relative contribution (\%) in surface layer of the eastern part of the Yellow Sea in summer 2009. Abbreviations of area $\mathrm{A}, \mathrm{B}, \mathrm{C}$, and $\mathrm{D}$ as per Fig. 8

의 미소형 및 소형 식물플랑크톤 현존량은 $10^{3} \sim 10^{6} \mathrm{cells}^{-1}$ 의 분포로 정점에 따라 큰 차이를 보이며 평균 $1.79 \times 10^{5}$ cells $1^{-1}$ 를 나타냈다. 각 선의 연안쪽 정점에서 $10^{5} \sim 10^{6}$ cells $1^{-1}$ 의 높은 현존량을 보인 반면 바깥쪽 정점에서는 $10^{3} \sim 10^{5}$ cells $^{-1}$ 의 낮은 현존량을 보였다(Fig. 4). 각 선에 서 현존량이 가장 높았던 연안쪽 정점에서는 식물플랑크 톤 군집에 우점하여 나타나는 종이 다소 달랐는데 307선 에서는 정점 3 에서 $10 \mu \mathrm{m}$ 이하 크기의 미소편모조류가 식물플랑크톤 현존량의 $71 \%$ 를 은편모조류가 $26 \%$ 를 차지 하여 나타났다. 308 선의 정점 1 에서는 미소편모조류가 $60 \%$, 은편모조류가 $29 \%$ 를 차지한데 이어 Dictyocha fibula가 식물플랑크톤 현존량의 $9 \%$ 를 차지하여 나타났다. 309 선의 정점 1 에서는 미소편모조류가 $68 \%$, 은편모조류 가 $6 \%$ 로 높은 우점율을 차지하여 나타났으나 Skeletonema spp., Thalassiosira spp. 등 규조류가 각각 $12 \%$ 와 $5 \%$ 를 차지하여 나타났고 그 외 Eucampia zodiacus, Chaetoceros spp. 등 다양한 규조류가 출현하였다. 310 선의 정점 3 에서 는 미소편모조류가 $78 \%$, 은편모조류가 $14 \%$ 로 우점하여 나타났으며 Prorocentrum 속, Scrippsiella trochoidea 등 다양한 와편모류가 출현하였고, 311 선의 정점 5 에서는 미 
소편모조류가 식물플랑크톤 현존량에 $98 \%$ 를 차지하여 나 타났다. 312선의 정점 5에서는 미소편모조류가 $69 \%$, 은 편모조류가 $27 \%$ 로 식물플랑크톤 우점종으로 출현하였는 데 저서성 규조류 Nitzschia spp.가 식물플랑크톤 현존량 의 $3 \%$ 를 차지하여 나타났다. 비록 $3 \%$ 의 낮은 우점율이나 저서성 규조류가 수심이 $70 \mathrm{~m}$ 이상인 312선 정점 5의 표 층에서 출현하였다. 이러한 현상은 312선의 다른 정점에 서도 나타나 정점 7에서는 저서성 규조류 Navicula spp.가 식물플랑크톤 현존량의 $49 \%$ 를 차지하며 우점하여 출현하 였으며 그 외 Paralia sulcata, Achnanthes sp., Skeletonema spp. 등이 각각 $3 \%$ 의 우점율로 나타났다. 2009년 하계에 312 선의 정점 5 와 정점 7의 표층에서 저서성 규조류가 출 현하여 나타난 것은 이 시기 인근해역에서 연안 용승에 의하여 수온, 염분, 영양염 농도가 표층으로 쐐기 모양의 분포구조를 보이는 것과 연관이 있어 보인다. 연안 용승에 의하여 312 선 정점 5 의 저층에 분포하는 저서성 규조류가 표층으로 유입되어 분포하였으며 바깥해역쪽인 정점 7 까 지 확산되어 나타났고 이 과정에서 표층에서의 호전된 광 조건으로 인하여 저서성 규조류가 일시적으로 성장하여 분포했을 것으로 생각된다.

\section{초미소식물플랑크톤 그룹}

2009년 6월 황해 동부수역의 표층에서 Synechococcus 그룹의 현존량은 307 선의 정점 3 에서 $9.17 \times 10^{2}$ cells $\mathrm{ml}^{-1}$ 로 가장 낮은 값을 312 선의 정점 5 에서 $1.93 \times 10^{5}$ cells ml${ }^{-1}$ 로 가장 높은 값을 보이며 평균 $3.02 \times 10^{4}$ cells $\mathrm{ml}^{-1}$ 를 나타냈다(Fig. 5). Synechococcus 그룹 현존량의 공 간적인 분포는 연안과 외해쪽 정점의 중간적인 해역에서 높은 값을 보였는데 북쪽 정점인 307 309선에서는 전이 수역인 정점 3과 정점 5에서 높았고, 남쪽인 311 312선에

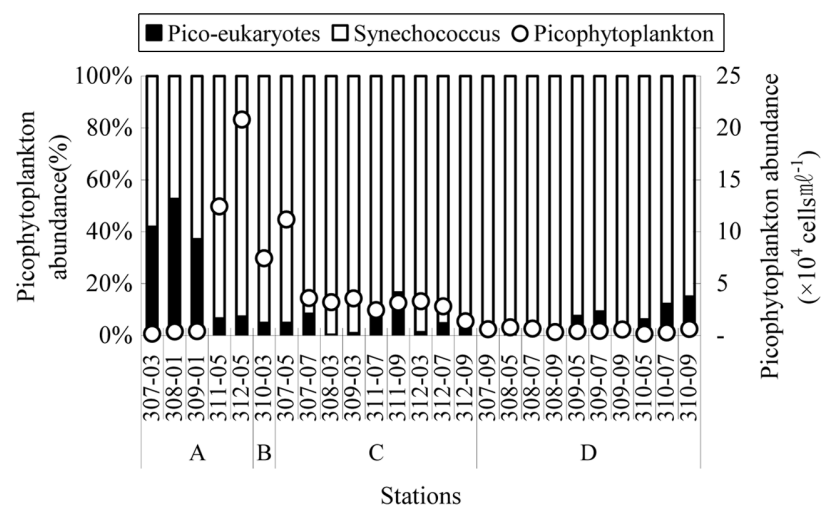

Fig. 5. Regional variations of picophytoplankton abundance (cells $\mathrm{ml}^{-1}$ ) and relative contribution (\%) of picophytoplankton groups in surface layer of the eastern part of the Yellow Sea in summer 2009. Abbreviations of area A, B, C, and D as per Fig. 8
서는 용승해역인 정점 5 에서 높은 현존량을 보여 황해 동 부수역의 북측과 남측이 다소 다른 양상을 나타냈다. Synechococcus 그룹의 현존량이 상대적으로 높았던 정점 은 연안의 탁한 환경으로부터 투명도가 급격이 깊어지기 시작하는 정점들과 일치하여 나타났으며 이는 초미소식물 플랑크톤 그룹이 수심이 얕고 투명도가 얕은 연안해역보 다 수심이 깊고 성층이 발달하여 광조건이 비교적 호전되 는 바깥해역에서 높은 성장을 보인데 기인한 것으로 판단 된다. 그러나 Synechococcus 그룹이 가장 높은 현존량을 보인 정점은 312 선의 정점 5 이다. 이는 하계에 식물플랑 크톤이 표층하 엽록소 최대층(deep chlorophyll-a maximum layer, DCM layer)에서 높은 현존량을 보이는 것과(Le et al. 2010) 달리 312선의 정점 5에서는 연안 용승으로 인하 여 표층으로 영양염이 활발히 공급된 것에 기인하는 것으 로 판단된다.

Pico-eukaryotes 그룹의 현존량은 308선의 정점 3, 5, 9 에서 100 cells ml-1 이하의 낮은 값을 312 선의 정점 5 에 서 $1.52 \times 10^{4}$ cells ml $\mathrm{m}^{-1}$ 로 가장 높은 값을 보이며 평균

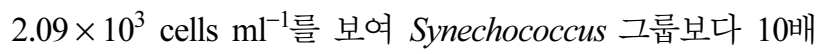
이상 낮은 현존량을 나타냈다(Fig. 5). 공간적인 분포는 연 안혼합수역에서 높은 현존량을 보여 Synechococcus 그룹 의 현존량 분포와 다소 다른 양상을 나타냈다.

\section{크기 구배에 따른 엽록소- $a$ 농도의 분포}

2009년 6월 황해 동부수역의 표층에서 엽록소-a의 농도 는 307 선의 정점 9 에서 $0.18 \mu \mathrm{g} \mathrm{l}^{-1}$ 로 최소값을, 310 선의 정점 3에서 $6.14 \mu \mathrm{g} \mathrm{l}^{-1}$ 로 최대값을 보이며 평균 $0.74 \mu \mathrm{g} \mathrm{l}^{-1}$ 를 나타냈다(Fig. 6). 공간적인 분포는 각 선의 연안쪽 정 점에서 외해보다 비교적 높은 값을 보였으며 바깥수역으 로 갈수록 낮은 엽록소-a 농도분포를 나타냈다. 엽록소-a

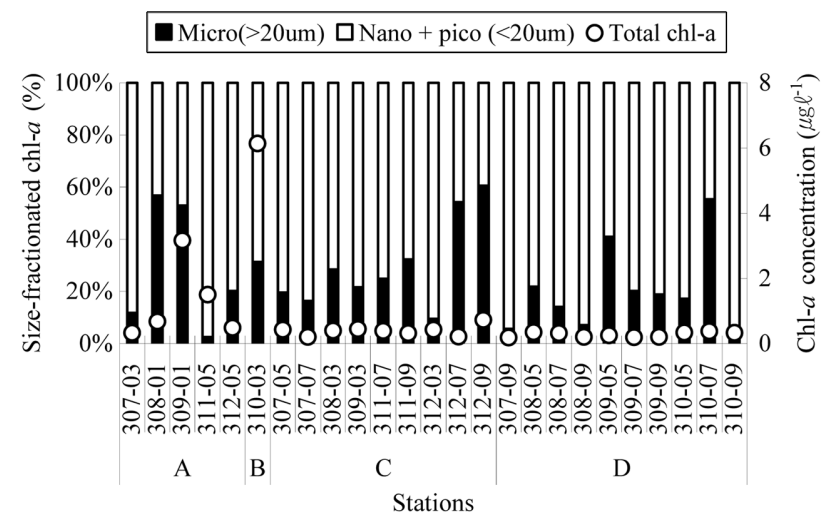

Fig. 6. Regional variations of size-fractionated chl-a composition and total chl-a concentration $\left(\mu \mathrm{g} \mathrm{I}^{-1}\right)$ in surface layer of the eastern part of the Yellow Sea in summer 2009. Abbreviations of area A, B, $C$, and $D$ as per Fig. 8 
농도의 크기구조는 $20 \mu \mathrm{m}$ 이상 크기의 소형 식물플랑크 톤의 엽록소-a가 평균 $26 \%, 20 \mu \mathrm{m}$ 이하의 미소형 및 초 미소형 식물플랑크톤의 엽록소-a가 평균 $74 \%$ 를 차지하여 작은 크기의 식물플랑크톤에 의하여 우점하는 양상을 나 타냈다(Fig. 6). 307선에서는 $20 \mu \mathrm{m}$ 이상 크기 구배의 엽 록소-a가 총 엽록소-a 농도에서 평균 $20 \%$ 이하를 차지하 며 정점별로 큰 차이를 보이지 않았으나 308 309선의 연 안쪽 정점에서는 $20 \mu \mathrm{m}$ 이상 크기 구배의 엽록소-a가 $50 \%$ 이상으로 외해쪽에 비하여 높은 값을 보여 연안해역 에서 식물플랑크톤 군집이 비교적 큰 크기의 식물플랑크 톤에 의하여 우점함을 나타냈다. 310 선에서도 연안쪽에서
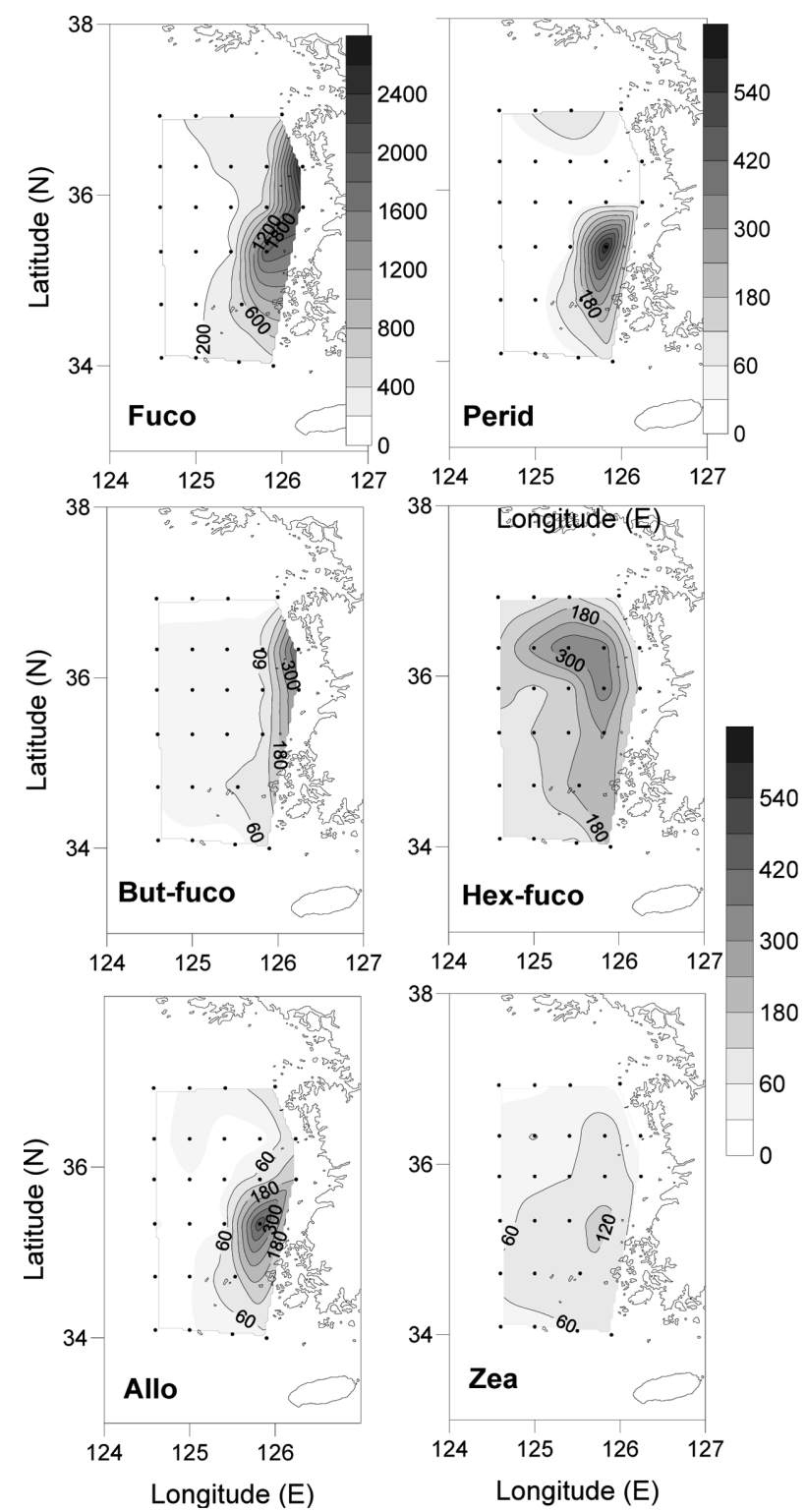

Fig. 7. Spatial distributions of depth-averaged Fuco, Perid, But-fuco, Hex-fuco, Allo, Zea $\left(\mathrm{ng}^{-1}\right)$ of the eastern part of the Yellow Sea in summer 2009. For abbreviation, refer the text
$20 \mu \mathrm{m}$ 이상 크기 구배에서 엽록소-a 농도의 우점율이 다 소 높았으나 311선과 312선에서는 연안보다 외해쪽 정점 에서 $20 \mu \mathrm{m}$ 이상 크기의 식물플랑크톤의 엽록소-a가 높은 우점율을 보여 반대의 양상을 나타냈다. 이는 식물플랑크 톤 군집의 현존량 분포를 반영하는 것으로 북쪽 해역에서 는 연안에서 큰 크기의 규조류와 황갈조편모류 등이 우점 하여 나타났으나 남쪽의 311,312 선에서는 연안 용승의 영향으로 다소 바깥해역에서 규조류 및 저서성 규조류가 우점하여 출현한데 기인하는 것으로 판단된다.

\section{황해 남동부 해역 광합성 색소의 분포 양상}

조사해역에서 광합성 색소는 Chlorophyll-c3, Chlorophyllc2, Peridinin(Perid), 19'-Butanoyloxyfucoxanthin(Butfuco), Fucoxanthin(Fuco), Prasinoxanthin, Violaxanthin, 19'-Hexanoyloxyfucoxanthin(Hex-fuco), Diadinoxanthin, Alloxanthin(Allo), Diatoxanthin, Zeaxanthin(Zea), Chlorophyll$b$, Chlorophyll-a(Chl-a) 등이 검출되었다. Fuco는 308선의 정점 1 에서 수심평균 $2,639 \mathrm{ng} \mathrm{l}^{-1}$ 로 가장 높았고 대체로 연안쪽 정점에서 높은 값을 보였으며 외해로 갈수록 급격 히 감소하는 농도분포로 엽록소-a 농도와 유사한 분포경 향을 보였다(Fig. 7). But-fuco도 연안쪽 정점에서 높고 외 해로 갈수록 농도가 낮아지는 경향을 보였다. 반면에 Perid는 정점에 따라 큰 농도차이를 보였다. 310선의 3번 정점에서 수심평균 $606 \mathrm{ng} \mathrm{l}^{-1}$ 로 가장 높은 농도를 보였으 며 307 선의 정점 5 와 311 선의 정점 5 에서 각각 수심평균

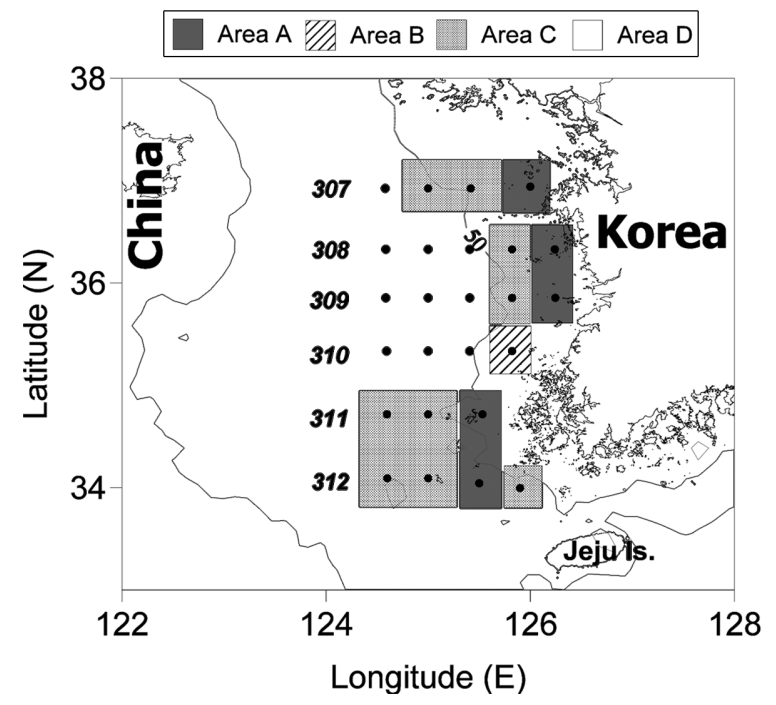

Fig. 8. Four areas by cluster analysis using phytoplankton group abundance in the eastern part of the Yellow Sea (Area A; Coastal mixing waters in the mid-eastern area of the Yellow Sea, Area B; The waters of western Anma Island, Area C; Transition waters, Area D; Central stratified waters of the Yellow Sea) 
$123 \mathrm{ng} \mathrm{l}^{-1}, 139 \mathrm{ng} \mathrm{l}^{-1}$ 로 비교적 높은 농도를 보인 반면 그 외의 정점에서는 매우 낮거나 검출한계 이하의 농도를 보 였다. Allo는 연안쪽 정점에서 비교적 높았는데 Perid가 높은 농도를 보인 310 선의 정점 3 에서 수심평균 $476 \mathrm{ng}^{-1}$ 로 가장 높은 농도를 보였다. Hex-fuco는 북쪽의 외해쪽 수역에서 비교적 높은 농도분포를 보였으며 Zea는 연안보 다는 외해쪽 수역에서, 북쪽보다는 남쪽 해역에서 비교적 높은 농도분포를 보였다.

\section{해역별 식물플랑크톤 분포특성과 환경요인}

식물플랑크톤 군집의 변동양상을 살펴보기 위하여 각 정점의 식물플랑크톤 그룹별 현존량 자료로부터 BrayCurtis 유사도 지수를 구하여 집괴분석(cluster analysis)을 실시하였고 약 $45 \%$ 의 유사도를 기준으로 네 개의 해역이 구분되었다(Fig. 8). 집괴분석 결과에 따르면 황해 동부해 역은 크게 네 개의 해역으로 나뉘는데 황해 동부의 연안 혼합해역(Area A), 안마도 서측해역(Area B), 전이수역 (Area C), 황해중앙수역(Area D)이다.

황해 동부 연안혼합해역(coastal mixing waters in the mideastern area of the Yellow Sea)

황해 동부의 연안혼합해역은 조사정점 중 연안쪽에 위 치하여 조석 혹은 연안용승 등 물리적 요인에 의하여 수 괴의 수직적 혼합이 활발히 이루어지는 해역에 해당한다. 307 선부터 309선의 경우 각 선의 가장 연안쪽에 위치한 정점에 해당되며 연안으로부터 유입되는 담수의 영향으로 염분이 해역 평균 $32.37 \mathrm{psu}$ 로 낮고, 조석전선이 발달해 있다(Table 1). 이로 인하여 투명도 수심이 해역 평균 $3.4 \mathrm{~m}$ 로 나타났으며 표층 용존무기 영양염류는 다른 해역 에 비하여 높은 농도를 보였다. 식물플랑크톤 현존량과 생 물량(엽록소-a)은 각 선에서 가장 높게 나타났으며 규조류 의 현존량이 식물플랑크톤 현존량에 차지하는 우점률이 비교적 높았다. 대부분의 광합성 색소 또한 상대적으로 높

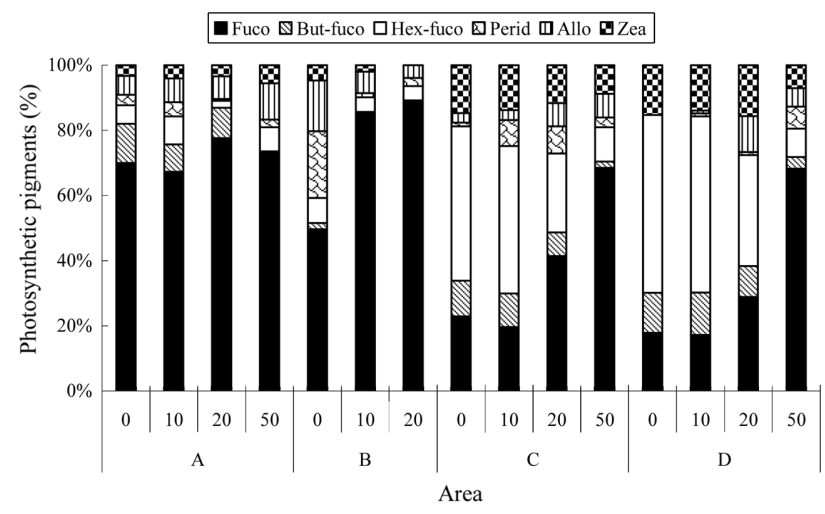

Fig. 9. The area-averaged photosynthetic pigments from four depths, $0,10,20$, and $50 \mathrm{~m}$, in the eastern part of the Yellow Sea in summer. Abbreviations of area as per Fig. 8

은 농도분포를 보이며 그 중 규조류의 지시색소인 Fuco의 비율이 높았고 수직적으로 광합성 색소 농도 차이는 보이 지 않았다(Fig. 9).

황해 중동부 연안의 혼합수역이 집괴분석을 통하여 하 나의 해역으로 나뉘었지만 이는 또 다시 위도에 따라 다 소 다른 식물플랑크톤 군집구조를 보였다. $2 \mu \mathrm{m}$ 이상 크 기의 소형 및 미소형 식물플랑크톤의 현존량에 차지하는 우점율로 보았을 때 미소편모조류와 은편모조류가 높은 현존량으로 대부분의 정점에서 최우점종으로 출현하였으 나 이 두 그룹을 제외한 비교적 큰 크기의 식물플랑크톤 그룹은 다소 다른 종조성을 보였다. 307선과 308선의 연 안에서는 Skeletonema spp., Thalassiosira spp., Eucampia zodiacus, Chaetoceros spp. 등의 규조류 혹은 황갈조편모 류 Dictyocha fibula가 우점하여 나타난 반면 311선과 312 선의 연안용승해역인 정점 5에서는 저서성 규조류가 우점 하여 나타났다. 310 선을 중심으로 북쪽과 남쪽의 연안 혼 합수역이 식물플랑크톤 종조성에 다소 차이를 보이는 것 은 수심, 조석차, 연안용승 등 수괴의 물리적 혼합이 차이

Table 1. Average environmental parameters ( \pm SD) of the surface layer in the eastern part of the Yellow Sea in summer. Abbreviations of area as per Fig. 8

\begin{tabular}{lcccc}
\hline Environmental parameters & Area A & Area B & Area C & Area D \\
\hline Temperature $\left({ }^{\circ} \mathrm{C}\right)$ & $18.67 \pm 2.48$ & 20.26 & $22.27 \pm 0.57$ & $22.28 \pm 0.35$ \\
Salinity $(\mathrm{psu})$ & $32.37 \pm 0.59$ & 32.63 & $32.47 \pm 0.23$ & $32.21 \pm 0.24$ \\
Nitrite $(\mu \mathrm{M})$ & $0.16 \pm 0.08$ & 0.09 & $0.12 \pm 0.09$ & $0.08 \pm 0.05$ \\
Nitrate $(\mu \mathrm{M})$ & $8.25 \pm 4.44$ & 2.34 & $5.20 \pm 3.96$ & $4.11 \pm 3.39$ \\
Phosphate $(\mu \mathrm{M})$ & $0.51 \pm 0.31$ & 0.17 & $0.40 \pm 0.40$ & $0.25 \pm 0.22$ \\
Silicate $(\mu \mathrm{M})$ & $5.73 \pm 4.27$ & 0.78 & $5.70 \pm 4.50$ & $7.03 \pm 4.28$ \\
N:P & $17.1 \pm 3.1$ & 14.5 & $15.4 \pm 5.2$ & $19.7 \pm 9.4$ \\
N:Si & $2.3 \pm 1.4$ & 3.1 & $1.1 \pm 0.6$ & $0.7 \pm 0.6$ \\
Si:P & $9.9 \pm 5.4$ & 4.7 & $16.5 \pm 9.2$ & $34.6 \pm 18.7$ \\
Transparency $(\mathrm{m})$ & $3.4 \pm 0.3$ & 3.0 & $8.1 \pm 0.3$ & $11.2 \pm 1.8$ \\
\hline
\end{tabular}


를 보이는데 기인하는 것으로 판단된다.

\section{안마도 서측해역(The waters of western Anma Island)}

안마도 서측해역인 310선의 정점 3은 Prorocentrum triestinum, Prorocentrum minimum, Scrippsiella trochoidea 등의 와편모류가 소형 및 미소형 식물플랑크톤 그룹에 우 점종으로 나타났는데 집괴분석을 통해 연안혼합수역과는 다른 하나의 해역으로 구분되었다. 안마도 서측해역은 전 체 조사정점 중 가장 높은 식물플랑크톤 현존량과 생물량 을 나타냈다. 광합성 색소 농도는 표층과 $10 \mathrm{~m}$ 이하 수심 에서 큰 차이를 나타냈는데 표층에서는 다른 수심에 비하 여 와편모류의 지시색소인 Perid의 농도가 높게 나타나 와 편모류 그룹이 우점한 식물플랑크톤 현존량 분포결과와 일치되는 양상을 보였고 $10 \mathrm{~m}$ 와 $20 \mathrm{~m}$ 수심에서는 Fuco가 높은 우점률로 나타났다(Fig. 9). 안마도 서측해역은 다른 연안혼합수역과 수괴의 물리적 특성에 다소 차이를 보였 다. 310 선 북쪽의 연안 정점들은 혼합수역으로써 조석에 의하여 수괴의 수직혼합이 활발하게 나타났으나 310선의 연안쪽 정점인 안마도 서측해역에서는 $30 \mathrm{~m}$ 이하의 얕은 수심에도 불구하고 표층과 저층 간에 수온과 염분의 차이 를 보였다(Fig. 3). 규조류와 달리 와편모류는 유영능력을 가지기 때문에 하계에 연안의 성층해역에서 유영능력이 없는 규조류보다 부유와 성장에 유리한 것으로 알려져 있 다(Smayda 1997; Resende et al. 2007). 따라서 각선의 가 장 연안쪽 정점에서 수괴 성층화 정도의 차이가 규조류와 와편모류의 분포차이를 가져온 원인 중 하나일 것으로 추 측된다. 수괴의 성층화 정도 뿐 아니라 영양염 농도 또한 다른 해역과 뚜렷한 차이를 보였다(Table 1). 전반적으로 연안쪽 정점에서 높은 영양염 농도를 보인 것과 달리 안 마도 서측해역의 표층에서는 집괴분석을 통해 구분되는 네 개의 해역 중 가장 낮은 표층 영양염 농도를 나타냈다. 표층에서 질산염과 아질산염은 $2.42 \mu \mathrm{M}$, 인산염은 $0.17 \mu \mathrm{M}$ 의 농도로 다른 해역에 비하여 2 배 이상 낮은 농도를 보 였다. 특히 표층 규산염의 농도는 $0.78 \mu \mathrm{M}$ 로 5.70 $7.03 \mu \mathrm{M}$ 의 농도분포를 보인 다른 해역에 비하여 매우 낮 은 농도를 나타냈다. 규산염은 규조류, 황갈조편모류 등의 각(frustule)을 이루는 중요한 요소로써 와편모류에게는 이 용되지 않는다. 영양염류의 화학양론(stochiometry)에 의 하면 $\mathrm{N}: \mathrm{Si}$ 비율이 1 이상, $\mathrm{Si}: \mathrm{P}$ 비율이 10 이하이면 식물 플랑크톤 성장에 제한이 될 수 있는 것으로 알려져 있다 (Justic et al. 1995). 안마도 서측해역의 표층에서는 규산 염의 농도 뿐 아니라 N:Si 비율이 $3.1, \mathrm{Si}: \mathrm{P}$ 비율이 4.7로 화학양론에 의하여도 식물플랑크톤, 특히 규조류의 성장 에 제한이 될 수 있는 것으로 판단된다. 안마도 서측해역 표층 영양염류의 농도가 4개의 해역 그룹 중 가장 낮았음 에도 불구하고 조사해역 중 가장 높은 표층 식물플랑크톤
현존량과 생물량을 보인 것은 규산염을 제외한 영양염류 의 농도가 식물플랑크톤 성장에 제한이 될 정도로 고갈되 지는 않은데 기인하는 것으로 생각된다. 투명도 수심은 $3.0 \mathrm{~m}$ 로 연안혼합수역보다 탁해 표층에 국한되어 높은 식 물플랑크톤 생물량을 나타낸 것으로 판단된다.

\section{전이수역(Transional waters)}

전이수역은 310선을 중심으로 공간적으로 북쪽과 남쪽 해역이 구분되는데 북쪽에서는 조석전선 바깥수역이, 남 쪽에서는 연안 용승해역의 주변수역이 포함된다. 전이수 역에서는 수온, 염분에 의한 성층이 발달하기 시작하며 혼 합수역에 비하여 표층 수온과 염분이 다소 높게 나타났고 표층 영양염류의 농도는 다소 낮게 나타났다(Table 1). 또 한 투명도 수심은 해역 평균 $8.1 \mathrm{~m}$ 로 연안역에 비하여 수 중 광조건이 호전되어 나타났다. 전이수역의 표층에서 식 물플랑크톤은 낮은 현존량과 생물량을 보였으며 미소편모 조류와 Synechococcus의 현존량이 $2 \mu \mathrm{m}$ 이상과 이하 크 기의 식물플랑크톤 그룹에서 각각 우점하는 것으로 나타 났다. 초미소식물플랑크톤은 연안역에서 소수그룹으로 그 역할이 다소 미약한 것으로 알려져 있으나(Iriarte and Purdie 1994) 용승대 인근해역이나 연안역 등의 중영양 (mesotrophic) 환경에서 높은 현존량을 보이는 것으로 보 고되어 있다(Partensky et al. 1999; Worden et al. 2004). 본 조사결과 초미소식물플랑크톤 그룹은 북쪽의 전이수역 에서 높은 현존량을 나타냈고 남쪽에서는 전이수역과 혼 합수역에서 높은 현존량을 보였다. 남쪽의 전이수역은 그 범위부터 북쪽과 달랐는데 북쪽의 전이수역이 연안혼합수 역 바로 인근 정점에 국한되어 구분된 반면 남쪽의 전이 수역은 311선과 312선의 용승대 인근해역부터 가장 바깥 정점까지 확장되어 나타났다. 이는 정 등 (2009)이 보고한 흑산도 인근해역에서 남서쪽 방향으로의 강한 조석잔차에 의한 영향으로 일부 설명할 수 있을 것으로 생각된다. 남 쪽의 전이수역에서는 저서성 규조류가 미소형 및 소형 식 물플랑크톤 그룹 현존량에 차지하는 우점률이 다소 높게 나타났는데 이는 흑산도 인근해역에서 연안용승에 의하여 저층에서 표층으로 유입된 저서성 규조류가 바깥 방향으 로의 조석잔차에 의하여 표층에서 확산되며 일부 성장하 여 나타났을 수 있는 것으로 추측된다. 이러한 저서성규조 류의 표층확산과 성장은 311선과 312선 정점 7의 표층에 서 현미경으로 분석된 식물플랑크톤 현존량에 대해 저서 성 규조류 Navicula spp., Paralia sulcata 등의 우점률이 $50 \%$ 이상까지 높게 나타나는 것으로 설명될 수 있으며 이 후 가장 바깥해역인 정점 9의 표층에서는 우점률이 크게 감소한 것으로 보아 표층 확산이 바깥해역에서 약화된 데 기인한 것으로 추측된다. 전이수역에서 식물플랑크톤 광 합성 색소는 수심별로 조성에 차이를 보였다. 표층에서는 
Hex-fuco의 농도가 다른 색소에 비하여 높았고 저층으로 갈수록 감소하였으며 저층에서는 Fuco의 농도가 높게 나타났다. $\mathrm{Zea}$ 의 농도 또한 표층에서 높고 저층에서 낮 은 값을 보여 광합성 색소의 수직적 분포차이를 나타냈 다(Fig. 9).

\section{황해 중앙 성충해역(Central stratified waters of the Yellow Sea)}

307선부터 310선의 바깥해역 정점에 속하는 황해중앙 해역에서는 성층이 강하게 발달하여 투명도 수심이 해역 평균 $11.2 \mathrm{~m}$ 로 집괴분석을 통해 구분된 해역 중 가장 깊 은 것으로 나타났으며 표층 영양염류의 농도 또한 전이수 역보다 다소 낮은 것으로 나타났다(Table 1). 표층 규산염 농도가 해역평균 $7.03 \mu \mathrm{M}$ 로 해역 그룹 중 가장 높은 농도 를 보였고 $\mathrm{N}: \mathrm{Si}$ 비가 평균 $0.7, \mathrm{Si}: \mathrm{P}$ 비가 평균 34.6으로 해역 그룹 중 각각 최저, 최고 값을 나타냈다. 식물플랑크 톤 현존량과 생물량은 매우 낮았고 Synechococcus와 미소 편모조류의 현존량이 다소 높게 나타났다. Hex-fuco는 황 해중앙해역과 전이수역에서 가장 우점하는 광합성 색소로 나타났는데 착편모류의 주요 지시색소이며 초미소식물플 랑크톤과 와편모류에서 일부 나타나기도 한다. 이는 황해 중앙해역에서 Hex-fuco를 색소로 가지는 작은 크기의 초 미소 및 미소편모조류가 식물플랑크톤 군집에 우점하여 나타날 수 있음을 보여준다. 황해중앙해역에서 광합성 색 소의 수직분포는 전이수역과 마찬가지로 다소 차이를 보 였는데 Hex-fuco는 표층에서 높은 농도를 보였다(Fig. 9). Zea 또한 저층보다 표층에서 높은 농도를 보여 Hex-fuco 와 유사한 수직분포를 보였다. 저층 $50 \mathrm{~m}$ 수심에서는 Fuco가 다소 높게 나타났다. 본 조사시에는 저층 해수의 현미경 분석이 이루어지지 않았으나 2008년 8월 황해 중 앙해역에서 이전 연구가 수행된 바 있다(UNDP/GEF 2011). 2008년 하계에 본 조사의 집괴분석을 통한 해역 그 룹 중 황해중앙해역에 속하는 정점에서 $77 \mu \mathrm{m}$ 네트로 수 직 채집한 결과 Chaetoceros lorenzianus가 우점종으로 나 타났으며 저층 해수의 현미경 분석 결과는 규조류 Navicula spp., Skeletonema spp.가 식물플랑크톤 현존량에 5\% 이상 을 차지하는 우점종으로 출현하여 저층에서 규조류의 지 시색소인 Fuco의 농도가 표층보다 높았던 본 조사결과와 일치하였다.

Synechococcus 그룹은 약 $1 \mu \mathrm{m}$ 의 직경을 가지며 작은 크기로 인하여 다른 식물플랑크톤 그룹보다 부유기작에 있어 유리하고 낮은 영양염 농도 하에서 큰 크기의 식물 플랑크톤보다 경쟁력이 높으며 높은 수온에서 성장률이 높게 나타나는 것으로 알려져 있다(Agawin et al. 2000; Timmermans et al. 2005). 황해 중앙해역에서는 하계에 표층수온 증가로 강한 성층이 형성되어 있으며 표층 영양
염이 고갈되거나 매우 낮게 나타나 이러한 환경 하에서 Synechococcus 그룹이 식물플랑크톤에 중요한 우점종으로 나타나는 것으로 보고되어 있다(Le et al. 2010). 자연상태 혹은 배양환경에서 초미소식물플랑크톤의 최대성장률은 약 $2 \mathrm{~d}^{-1}$ (Agawin et al. 1998), 소형식물플랑크톤은 평균 $2.2 \mathrm{~d}^{-1}$ (Banse 1982)를 보이며 착편모류는 종에 따라 최대 $2.23 \mathrm{~d}^{-1}$ (Seoane et al. 2009)의 성장률을 보이는 것으로 보고되어있다. Agawin et al. (2000)은 질산염 농도 약 $1 \mu \mathrm{M}$ 이상에서 초미소식물플랑크톤은 미소형, 소형식물 플랑크톤보다 성장속도가 느려 우점률이 급격히 감소하나 그 이하의 질산염 농도에서는 식물플랑크톤 군집에 우점 한다고 하였다. 하계에 황해 중앙해역은 성층이 강화됨에 따라 $20 \mu \mathrm{m}$ 이상 소형 크기의 식물플랑크톤보다 $20 \mu \mathrm{m}$ 이하 크기의 초미소형 및 미소형 크기의 식물플랑크톤 그 룹이 성장에 유리한 수괴구조를 보인다. 이와 같이 영양염 농도 분포와 성층화된 수괴구조 등의 환경 요인으로 인하 여 2009년 6월 황해 중앙해역에서는 Hex-fuco를 색소로 가지는 초미소 및 미소편모조류가 우점하여 나타났을 수 있다.

해양환경의 변동에 의한 bottom-up 조절뿐 아니라 상위 포식자에 의한 top-down 조절의 가능성도 배제할 수는 없 다. 일례로 한반도 주변해역에서 동물플랑크톤 현존량이 1990년도 이후 점차 증가하며(Rebstock and Kang 2003) 특히 서해에서는 1990 년도 이후 요각류와 난바다곤쟁이 류 현존량이 증가하는 시기가 4월에서 6월로, 동물플랑크 톤 생물량이 년중 가장 높은 값을 보이는 시기가 6월로 나타난다(강 2008). 또한 Guo (1994)는 동물플랑크톤의 포식압이 황해에서 식물플랑크톤의 중요한 제한요소가 될 수 있다고 한 바 있다. 이는 전이수역과 황해 중앙 해역의 표층에서 비교적 높은 영양염 농도 분포를 보임에도 불구 하고 식물플랑크톤 생물량(엽록소-a)이 평균 $0.3 \mu \mathrm{g} \mathrm{l}^{-1}$ 으 로 낮은 값을 보이며 작은 크기의 초미소 및 미소편모조 류가 우점하는 데에 동물플랑크톤의 포식압 또한 중요한 제한요인 중 하나가 될 수 있음을 암시한다. 그러나 이러 한 가설과 추측은 제한적인 조사해역과 시기로 인하여 한 계점을 가지고 있으며 추가적인 연구를 통하여 규명되어 야할 필요가 있는 것으로 생각된다.

\section{사 사}

본 연구는 2011년도 한국연구재단 일반연구자지원사업 황해 난류수 유입과 기후변화에 따른 황해 난수성 동, 식 물플랑크톤 분포 동태(2010-0010162) 과제의 지원으로 수 행되었으며, 논문을 세심하게 심사해주시고 조언해주신 두 분의 심사위원과 현장조사에 도움을 주신 국립수산과 학원 서해수산연구소 연구진, 탐구8호 승조원 여러분, 그 
리고 시료채집에 도움을 준 전석진군에게 진심으로 감사 드립니다.

\section{참고문헌}

강영실 (2008) 북태평양체제전환(North Pacific Regime Shifts)과 한반도 주변해역 동물플랑크톤 계절주기 변동 특성. 한국수산학회지 41:493-504

강태연, 최영찬, 고유봉 (1996) 제주도 주변 용승역의 생물생 태학적 기초연구(I): 제주도 남서부 연안해역의 해수화학 적 특성과 용승현상. 한국수산학회지 29:603-613

윤양호, 박종식, 박영균, 노일현 (2007) 여름 한국서남해역의 해양환경과 식물플랑크톤 군집분포. 한국해양환경공학회 지 10:155-166

정희동, 권철휘, 김상우, 조규대 (2009) 한국 서남해역에서 조 석전선의 변동과 저수온역 확장시작. 해양환경안전학회 지 15:289-296

조성환, 윤원득, 임동현, 최중기, 노재훈, 전형진, 송태윤 (1999) 황해 식물플랑크톤군집의 엽록소 a, 기초생산력 및 크기별 분류군의 시·공 분포. Bull Nat'l Fish Res Dev Inst Korea 57:163-173

최중기 (1991) 황해 중 - 동부 연안 수역의 조석전선이 식물 플랑크톤 생산력과 분포에 미치는 영향. 한국해양학회지 「바다」 26:223-241

황학진 (2010) 황해 동부역 자치어와 저어류의 시공간 분포. 이학박사 학위논문, 인하대학교, $116 \mathrm{p}$

Agawin NSR, Duarte CM, Agusti S (1998) Growth and abundance of Synechococcus sp. in a Mediterranean Bay: Seasonality and relationship with temperature. Mar Ecol-Prog Ser 170:45-53

Agawin NSR, Duarte CM, Agusti S (2000) Nutrient and temperature control of the contribution of picoplankton to phytoplankton biomass and production. Limnol Oceanogr 45:591-600

Banse K (1982) Cell volumes, maximal growth rates of unicellular algae and ciliates, and the role of ciliates in the marine pelagial. Limnol Oceanogr 27:1059-1071

Choi JK (2002) Phytoplankton Ecology in the Yellow Sea. In: Lee D (ed) Ecology of Korea. Bumwoo Publishing Company, Seoul, pp 311-330

Crumpton WG (1987) A simple and reliable method for making permanent mounts of phytoplankton for light and fluorescence microscopy. Limnol Oceanogr 32:1154-1159

Guo YJ (1994) Primary productivity and phytoplankton in China Seas. In: Zhou D, Liang YB, Zeng CK (eds) Oceanology of China Seas. Kluwer Academic Publishers, Boston, pp 227-242

Heileman S, Jiang Y (2009) Yellow Sea LME. In: Sherman $\mathrm{K}$, Hempel G (eds) The UNEP large marine ecosystem report: A perspective on changing conditions in LMEs of the world's Regional Seas. UNEP Regional Seas Report and Studies No. 182. United Nations Environment Programme, Nairobi, Kenya, pp 441-452

Jing ZY, Hua ZL, Qi YQ, Cheng XH (2007) Numerical study on the coastal upwelling and its seasonal variation in the East China Sea. J Coastal Res 50:555-563

Justic D, Rabalais NN, Turner RE, Dortch Q (1995) Changes in nutrient structure of river-dominated coastal waters: Stoichiometric nutrient balance and its consequences. Estuar Coast Shelf Sci 40:339-356

Kang SH, Fryxell GA (1991) Most abundant diatom species in water column assemblages from five ODP Leg 119 drill sites in Prydz Bay, Antarctica: Distributional patterns. In: Barron J, Larsen B (eds) Proceeding of the ocean drilling program, scientific results, 119. Ocean Drilling Program, College Station, Texas, pp 645-666

Kang SH, Kang JS, Lee S, Chung KH, Kim D, Park MG (2001) Antarctic phytoplankton assemblages in the marginal ice zone of the northwestern Weddell Sea. J Plankton Res 23:333-352

Le F, Ning X, Liu C, Hao Q, Shi S (2010) Community structure of picoplankton abundance and biomass in the southern Huanghai Sea during the spring and autumn of 2006. Acta Oceanol Sin 29:58-68

Mantoura RFC, Repeta DJ (1997) Phytoplankton pigments in oceanography: Guidelines to modern methods. In: Jeffrey SW, Mantoura RFC, Wright SW (eds) Calibration method for HPLC. UNESCO Publishing, pp 407-428

Marie D, Partensky F, Jacquet S, Vaulot D (1997) Enumeration and cell-cycle analysis of natural populations of marine picoplankton by flow cytometry using the nucleic-acid stain SYBR Green I. Appl Environ Microb 14:113-118

Nakata S, Sasajima YI, Hirose N, Yoshikawa Y, Yoon JH (2010) A study of the dynamic factors of the summertime upwelling in the Tsushima Warm Current region. Deep-Sea Res II 57:1799-1808

Partensky F, Blanchot J, Vaulot D (1999) Differential distribution and ecology of Prochlorococcus and Synechococcus in oceanic waters: A review. In: Charpy L, Larkum AWD (eds) Marine cyanobacteria. Bulletin de l'Institut Oceanographique Monaco, Musee oceanographique, Monaco, pp 457-475

Parsons TR, Maita Y, Lalli CM (1984) A manual of chemical and biological methods for seawater analysis. Pergamon Press, Oxford, $173 \mathrm{p}$

Rebstock GA, Kang YS (2003) A comparison of three marine ecosystems surrounding the Korean peninsula: Responses to climate change. Prog Oceanogr 59:357-379 
Resende P, Azeiteiro UM, Gonalves F, Pereira F, Pereira MJ (2007) Distribution and ecological preferences of diatoms and dinoflagellates in the west Iberian Coastal zone (North Portugal). Acta Oecol 32:224-235

Seoane S, Zapata M, Orive E (2009) Growth rates and pigment patterns of haptophytes isolated from estuarine waters. J Sea Res 62:286-294

Seung YH, Chung JH, Park YC (1990) Oceanographic studies related to the tidal front in the mid-Yellow Sea of Korea: Physical aspects. J Oceanol Soc Korea 25:84-95

Sieburth JMcN (1978) Pelagic ecosystem structure: Heterotrophic compartments of the plankton and their relationship to plankton size fractions. Limnol Oceanogr 23:1256-1263

Smayda TJ (1997) Harmful algal blooms: Their ecophysiology and general relevance to phytoplankton blooms in the sea. Limnol Oceanogr 42:1137-1153

Takahashi M, Bienfang PK (1983) Size structure of phytoplankton biomass and photosynthesis in subtrophical Hawaiian waters. Mar Biol 76:203-211

Tang Q (2003) The Yellow Sea LME and mitigation action. In: Hempel G, Sherman K (eds) Large marine ecosystems of the world-trends in exploitation, protection and research.
Elsevier BV, Amsterdam, pp 121-144

Timmermans KR, Wagt B, Veldhuis MJW, Maatman A, Baar HJW (2005) Physiological responses of three species of marine pico-phytoplankton to ammonium, phosphate, iron and light limitation. J Sea Res 53:109120

UNDP/GEF (2011) Seasonal variation of the major environment parameters in the Yellow Sea basin. UNDP/GEF Yellow Sea project, Ansan, Korea, pp 39-48

Worden AZ, Nolan JK, Palenik B (2004) Assessing the dynamics and ecology of marine picophytoplankton: The importance of the eukaryotic component. Limnol Oceanogr 49:168-179

Zapata M, Rodriquez F, Garrido JL (2000) Sepration of chlorophylls and carotenoids from marine phytoplankton: A new HPLC method using a reversed phase C8 column and pyridine-containing mobile phases. Mar Ecol-Prog Ser 195:29-45 